\title{
Antibodies to cytomegalovirus in homosexual and heterosexual men attending an STD clinic
}

\author{
A MINDEL* AND S SUTHERLAND† \\ From the Academic Departments of *Genitourinary Medicine and +Virology, The Middlesex Hospital \\ Medical School, London
}

SUMMARY We studied the prevalence of antibody to cytomegalovirus (CMV) in 262 men (132 homosexual, 20 bisexual, and 108 heterosexual) attending the sexually transmitted diseases (STD) clinic at this hospital. Antibody to CMV at a titre of $1 / 4$ or more was found in $92 \%$ of the homosexuals, $80 \%$ of the bisexuals, and $56 \%$ of the heterosexuals $(p<0.0001)$. Among heterosexuals, but not homosexuals, nationality and social class showed a significant association with antibody to CMV. In both heterosexuals and homosexuals a history of gonorrhoea was more common in patients with antibody to CMV than in those without it. A similar finding was seen in heterosexual men with a history of non-specific urethritis (NSU). Using a series of log linear models, sexual orientation was shown to be the most important determinant of antibody to CMV in this population.

\section{Introduction}

Infection with cytomegalovirus (CMV) is widespread, but the age at which the infection is acquired varies from one country to another. Antibody studies have shown that in many parts of the world the infection is acquired very early in childhood and that $95-100 \%$ of children are infected by 3-5 years old. ${ }^{1}$ In the United Kingdom, most of Western Europe, and North America $50-60 \%$ of the population will eventually acquire the infection; about a third in childhood and the rest between the ages of 15 and 35 years. ${ }^{2}$ Most of these infections are mild or asymptomatic, but some cause considerable morbidity and occasionally death in recipients of bone marrow transplants ${ }^{3}$ and in children infected in utero. ${ }^{4}$ Infection with $\mathrm{CMV}$ may be sexually transmitted, ${ }^{56}$ and antibody to the virus is commonly detected in male homosexuals. ${ }^{78}$ More recently the virus has been associated with the acquired immune deficiency syndrome (AIDS) in homosexual men. ${ }^{910}$

We compared the prevalence of antibody to CMV in homosexuals and heterosexuals attending the sexually transmitted disease (STD) clinic at this hospital and studied the role of factors such as history of STD, age, social class, and nationality in the acquisition of antibody to CMV.

Address for reprints: Dr A Mindel, James Pringle House, The Middlesex Hospital, London WIN 8AA

Accepted for publication 11 October 1983

\section{Patients and methods}

STUDY POPULATION

All men attending the STD clinic at this hospital during the week 22-26 March 1982 who had blood taken for syphilis tests were included in the study. Blood was taken from 276 men but only 262 samples were available for analysis (insufficient serum was available from six patients, four specimens were mislaid or broken, and four were incorrectly labelled). Patient notes were analysed retrospectively for age, sexual preference, social class, previous STD, and nationality. We used two categories of nationality; areas of high risk of early CMV transmission (Africa, Asia, Middle and Far East, Mediterranean, Central and South America), and areas of low risk of CMV transmission (United Kingdom, Europe, North America and Australasia). (Australasia was included as a low risk area as most clinic attenders from there were middle class white patients). The number of bisexual patients was small and in the analyses of most variables they were included with the homosexual patients.

\section{TEST METHODS}

CMV antibody was measured by the complement fixation test using a microtitre method. ${ }^{11}$ The antigen was obtained from Flow Laboratories, Irvine, Scotland, and the test was performed using four haemolytic doses of complement. The serum samples were screened at dilutions of $1 / 4$ and 1/128 and all 
those showing fixation at $1 / 128$ were titrated to determine the end point.

\section{STATISTICAL ANALYSIS}

The data were analysed by the $\chi^{2}$ and Fisher's exact probability tests. A series of log linear models was fitted in order to assess the relative importance of the variables used in determining the presence of antibody to CMV.

\section{Results}

Antibody to CMV at a titre of $\geqslant 1 / 4$ was detected in 197 patients $(75 \%)$. The mean (SD) age of the patients with antibody was similar to that of men with no antibody $(30.9(9 \cdot 1) \vee 30.0(8 \cdot 1)$ years). Analysis by sexual preference showed that $121(92 \%)$ of the 132 homosexuals, $16(80 \%)$ of the 20 bisexuals and $60(56 \%)$ of the 108 heterosexuals had antibody to CMV at a titre of $\geqslant 1 / 4(p<0 \cdot 0001)$. Twenty six patients had antibody to CMV at a titre of $\geqslant 1 / 128$, and $23(89 \%)$ of these were homosexual or bisexual $(\mathrm{p}<0.05)$.

The figure shows the percentage of homosexuals (including bisexuals) and heterosexuals with antibody to CMV at a titre of $\geqslant 1 / 4$ analysed by social class. In the heterosexual group there was an increase in the percentage of patients with antibody from $40 \%$ in social class I to $100 \%$ in social class $V$. In the homosexual group the trend was similar but less pronounced. The difference in prevalence of antibody (at titres of $\geqslant 1 / 4$ ) between homosexuals and heterosexuals by social class was significant $(\mathrm{p}>0 \cdot 01)$.

Table I shows the nationality of the patients comparing high risk and low risk areas and sexual orientation. All but two of the patients from high risk areas had CMV antibodies at a titre of $\geqslant 1 / 4$, whereas in the low risk areas only $74 \%$ of patients had antibody $(p<0.05)$. In homosexuals nationality did not correlate significantly with the antibody status. In heterosexuals, however, $89 \%$ of men from high risk areas were positive compared with only

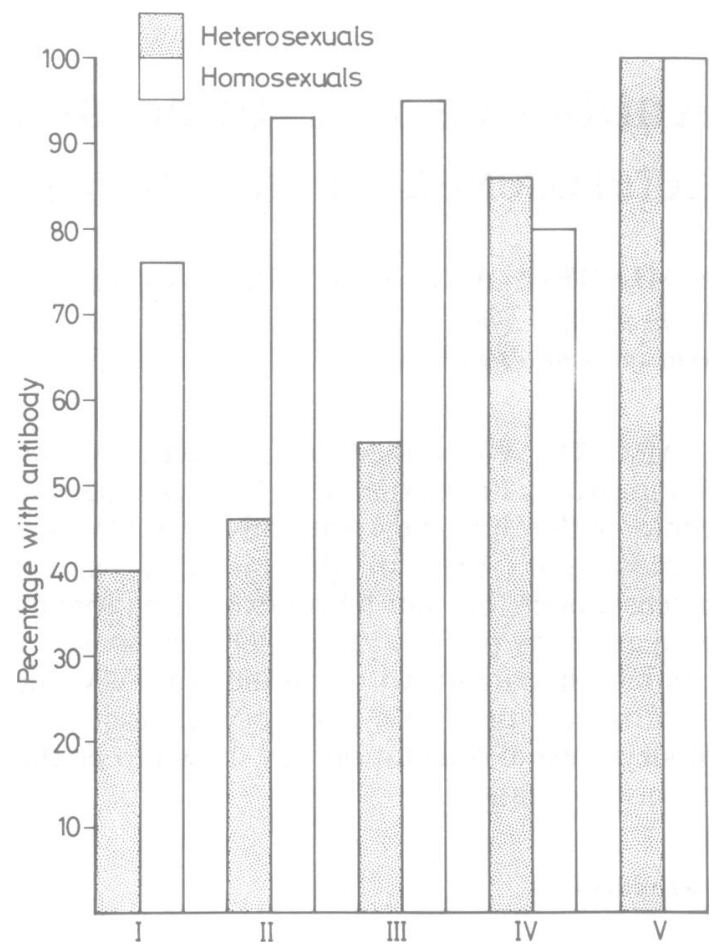

FIGURE Percentage of patients with antibody to CMV compared by social class and sexual orientation. (Differences in prevalence between homosexuals and heterosexuals by social class was significant $(p<0.01)$.

$49 \%$ in the low risk areas $(\mathrm{p}<0 \cdot 005)$. In the low risk areas there was a considerable difference between heterosexuals and homosexuals with $49 \%$ of the former and $89 \%$ of the latter having antibodies to CMV (p<0.0001).

The mean (SD) age of the homosexuals and bisexuals was $30 \cdot 1(8 \cdot 2)$ and of the heterosexuals $31 \cdot 6(9 \cdot 7)$. Table II shows antibody status analysed by age. The percentage of patients with antibody to CMV was similar in those under 30 and over 30 in

TABLE I Prevalence of antibody to CMV in patients compared by nationality and sexual orientation

\begin{tabular}{|c|c|c|c|c|c|}
\hline \multirow[b]{3}{*}{$\begin{array}{l}\text { Sexual } \\
\text { orientation }\end{array}$} & \multicolumn{4}{|c|}{ Patients from: } & \multirow[b]{3}{*}{ Significance } \\
\hline & \multicolumn{2}{|c|}{ High risk areas* } & \multicolumn{2}{|c|}{ Low risk areast } & \\
\hline & $\begin{array}{l}\text { No of } \\
\text { men }\end{array}$ & $\begin{array}{l}\text { No (\%) with } \\
\text { antibody }\end{array}$ & $\begin{array}{l}\text { No of } \\
\text { men }\end{array}$ & $\begin{array}{l}\text { No (\%) with } \\
\text { antibody }\end{array}$ & \\
\hline $\begin{array}{l}\text { Heterosexual } \\
\text { Bisexual and homosexual }\end{array}$ & $\begin{array}{l}18 \\
10\end{array}$ & $\begin{array}{l}16(89) \\
10(100)\end{array}$ & $\begin{array}{r}90 \\
142\end{array}$ & $\begin{array}{r}44(49) \\
127(89)\end{array}$ & $\begin{array}{l}\mathrm{p}<0.005 \\
\mathrm{NS}\end{array}$ \\
\hline Total & 28 & $26(93)$ & 232 & $171(74)$ & $\mathrm{p}<0.05$ \\
\hline
\end{tabular}

*Africa, Asia, Middle and Far East, Mediterranean, and Central and South America; †United Kingdom, Europe, North America, and Australasia. 
TABLE II Prevalence of antibody to CMV in patients compared by age and sexual orientation

\begin{tabular}{|c|c|c|c|c|c|}
\hline \multirow[b]{3}{*}{ Age } & \multicolumn{4}{|c|}{ Sexual orientation: } & \multirow[b]{3}{*}{ Significance } \\
\hline & \multicolumn{2}{|c|}{ Heterosexual } & \multicolumn{2}{|c|}{ Bisexual and homosexual } & \\
\hline & $\begin{array}{l}\text { No of } \\
\text { men }\end{array}$ & $\begin{array}{l}\text { No (\%) with } \\
\text { antibody }\end{array}$ & $\begin{array}{l}\text { No of } \\
\text { men }\end{array}$ & $\begin{array}{l}\text { No (\%) with } \\
\text { antibody }\end{array}$ & \\
\hline $\begin{array}{l}17-29 \\
\text { Over } 30\end{array}$ & $\begin{array}{l}54 \\
54\end{array}$ & $\begin{array}{l}28(52) \\
32(59)\end{array}$ & $\begin{array}{l}83 \\
69\end{array}$ & $\begin{array}{l}78(94) \\
64(93)\end{array}$ & $\begin{array}{l}\mathrm{p}<0.0001 \\
\mathrm{p}<0.0001\end{array}$ \\
\hline Total & 108 & $60(56)$ & 152 & $142(93)$ & $\mathrm{p}<0.0001$ \\
\hline
\end{tabular}

both homosexuals and heterosexuals, but significantly $(\mathrm{p}<0.0001)$ more homosexuals in both age groups had antibody.

Table III shows previous STD comparing patients with antibody to those without it. When all the patients are considered, CMV antibody was

TABLE III Prevalence of antibody to CMV in patients compared by history of STD and sexual orientation

\begin{tabular}{|c|c|c|c|}
\hline History of STD & $\begin{array}{l}\text { No (\%) with } \\
\text { antibody }\end{array}$ & $\begin{array}{l}\text { No (\%) without } \\
\text { antibody }\end{array}$ & Significance \\
\hline $\begin{array}{l}\text { All patients } \\
\text { Syphilis } \\
\text { Gonorrhoea } \\
\text { NSU } \\
\text { Herpes } \\
\text { Warts } \\
\text { Any STD }\end{array}$ & $\begin{array}{c}(n=195) \\
56(29) \\
104(53) \\
85(44) \\
16(8) \\
30(15) \\
148(76)\end{array}$ & $\begin{array}{c}(n=63) \\
2(3) \\
9(14) \\
17(27) \\
3(5) \\
10(16) \\
29(46)\end{array}$ & $\begin{array}{l}\mathrm{p}=0 \cdot 0001 \\
\mathrm{p}<0 \cdot 0001 \\
\mathrm{p}<0 \cdot 1 \\
\mathrm{NS} \\
\mathrm{NS} \\
\mathrm{p}<0 \cdot 0001\end{array}$ \\
\hline $\begin{array}{l}\text { Bisexual and } \\
\text { Homosexual } \\
\text { Syphilis } \\
\text { Gonorrhoea } \\
\text { NSU } \\
\text { Herpes } \\
\text { Warts } \\
\text { Any STD }\end{array}$ & $\begin{array}{l}(n=137) \\
53(39) \\
85(62) \\
62(45) \\
14(10) \\
27(19) \\
115(84)\end{array}$ & $\begin{array}{l}(n=15) \\
2(13) \\
3(20) \\
6(40) \\
2(13) \\
2(13) \\
11(73)\end{array}$ & $\begin{array}{l}\text { NS } \\
\text { p<0.005 } \\
\text { NS } \\
\text { NS } \\
\text { NS } \\
\text { NS }\end{array}$ \\
\hline $\begin{array}{l}\text { Heterosexual } \\
\text { Syphilis } \\
\text { Gonorrhoea } \\
\text { NSU } \\
\text { Herpes } \\
\text { Warts } \\
\text { Any STD }\end{array}$ & $\begin{aligned}(n=58) \\
3(5) \\
19(33) \\
23(40) \\
2(3) \\
3(5) \\
33(57)\end{aligned}$ & $\begin{aligned}(n=48) \\
0(0) \\
6(13) \\
11(23) \\
1(2) \\
8(17) \\
18(38)\end{aligned}$ & $\begin{array}{l}\text { NS } \\
p<0.05 \\
p<0 \cdot 05 \\
\text { NS } \\
\text { NS } \\
p<0.1\end{array}$ \\
\hline
\end{tabular}

NSU $=$ non-specific urethritis. associated with a history of gonorrhoea, syphilis, or any STD. Of the patients with CMV antibody, 104 $(53 \%)$ had had gonorrhoea compared with only 9 $(14 \%)$ of those without antibody $(p<0.001)$. Of those with CMV antibody, $56(29 \%)$ had had syphilis but only $2(3 \%)$ of those without antibody had had the infection $(p<0.001)$. Gonorrhoea and nonspecific urethritis were associated with CMV antibodies ( $p<0.05$ in both cases) in heterosexual patients; other STDs occurred in only a few heterosexuals. Although a greater percentage of bisexual and homosexual patients with antibody had had syphilis, gonorrhoea, non-specific urethritis (NSU), and warts, the difference between them and those without antibody was only significant $(p<0.005)$ for gonorrhoea. Other STDs including trichomoniasis, hepatitis A, hepatitis B, and candidosis were uncommon infections in both groups of patients and were not associated with CMV antibody.

Table IV shows the variables in order of importance of their relation to CMV antibody. In all patients sexual orientation was the most important variable followed by gonorrhoea, syphilis, or any STD. In heterosexuals nationality was the only significant variable at the $10 \%$ level. Using log linear models, no combination of variables (or their interactions) could be found which contributed significantly (at the $5 \%$ level) to explaining the presence or absence of antibody to CMV in heterosexuals or homosexuals.

TABLE IV Antibody to CMV-Variables in order of importance

\begin{tabular}{|c|c|c|c|c|c|}
\hline \multicolumn{2}{|l|}{ All patients } & \multicolumn{2}{|c|}{ Bisexuals and homosexuals } & \multicolumn{2}{|l|}{ Heterosexuals } \\
\hline Variable & Significance & Variable & Significance & Variable & Significance \\
\hline $\begin{array}{l}\text { Sexual orientation } \\
\text { Previous gonorrhoea } \\
\text { Previous syphilis } \\
\text { Previous STD } \\
\text { Previous NSU } \\
\text { Nationality } \\
\text { Social Class } \\
\text { Age }\end{array}$ & $\begin{array}{l}\mathrm{p}<0.005 \\
\mathrm{p}<0.01 \\
\mathrm{p}<0.05 \\
\mathrm{p}<0.05 \\
0.2<\mathrm{p}<0.3 \\
0.3<\mathrm{p}<0.5 \\
0.9<\mathrm{p}<0.95 \\
0.95<\mathrm{p}<0.98\end{array}$ & $\begin{array}{l}\text { Previous gonorrhoea } \\
\text { Previous syphilis } \\
\text { Previous STD } \\
\text { Nationality } \\
\text { Previous NSU } \\
\text { Age } \\
\text { Social Class }\end{array}$ & $\begin{array}{l}0.3<\mathrm{p}<0.5 \\
0.5<\mathrm{p}<0.7 \\
0.7<\mathrm{p}<0.8 \\
0.7<\mathrm{p}<0.8 \\
0.8<\mathrm{p}<0.9 \\
\mathrm{p}=0.95 \\
0.95<\mathrm{p}<0.99\end{array}$ & $\begin{array}{l}\text { Nationality } \\
\text { Previous gonorrhoea } \\
\text { Previous syphilis } \\
\text { Previous NSU } \\
\text { Previous STD } \\
\text { Social Class } \\
\text { Age }\end{array}$ & $\begin{array}{l}0 \cdot 05<\mathrm{p}<0 \cdot 1 \\
0 \cdot 1<\mathrm{p}<0 \cdot 2 \\
0 \cdot 2<\mathrm{p}<0 \cdot 3 \\
0 \cdot 2<\mathrm{p}<0.3 \\
0 \cdot 2<\mathrm{p}<0 \cdot 3 \\
0 \cdot 2<\mathrm{p}<0.3 \\
0 \cdot 5<\mathrm{p}<0.7\end{array}$ \\
\hline
\end{tabular}

$\mathrm{NSU}=$ non-specific urethritis. 


\section{Discussion}

Most (90\%) homosexual men in this study compared with just over half the heterosexual men had antibody to CMV. These findings confirm those of a study in San Francisco in which $96 \%$ of homosexuals and $53 \%$ of heterosexuals had antibody to the virus. ${ }^{7}$ Other studies also support the view that CMV is a common homosexual infection. ${ }^{8} 10$ Homosexuality outweighed the other known factors (age, ${ }^{12}{ }^{13}$ social class, and nationality ${ }^{14}$ ) associated with acquisition of antibody.

Not suprisingly, a history of STD was associated with antibodies to CMV in both heterosexuals and homosexuals, and some STDs carried a greater risk than others. Gonorrhoea in particular appeared to be associated with CMV antibodies in both groups, whereas NSU, which was common in both groups, was only associated with an increased risk in heterosexuals. It is not clear why these two similar diseases carry different risks with regard to CMV.

CMV has recently been suggested as a possible cause of AIDS, and several studies have shown that many people with AIDS have high antibody titres to CMV and may be excreting the virus in the semen or urine. ${ }^{15} 16$ The role of CMV in AIDS is difficult to establish and, as most homosexual men have antibody to CMV, it is unlikely to be a direct cause of the syndrome. It is more likely that acquisition of CMV in adulthood may depress cellular immunity and allow opportunist infections to occur, possibly including the cause of AIDS. Alternatively, AIDS may be caused by many factors, one of which may be CMV. Kaposi's sarcoma occurring in young adults is now recognised as part of the syndrome. This rare tumour has been associated seroepidemiologically with CMV infection in Europe ${ }^{17}$ and America. ${ }^{18}$ In tropical Africa where a more virulent form of the tumour occurs in young men, the association with CMV is difficult to establish as there is a very high background level of antibody to CMV in the community. ${ }^{18} 19$ Two additional pieces of evidence suggest that CMV may be implicated in the pathogenesis of Kaposi's sarcoma; the first was the finding of CMV genetic material in Kaposi's sarcoma biopsies using deoxyribosenucleic acid (DNA) hybridisation techniques, ${ }^{20}$ and the second was the observation that cases of Kaposi's sarcoma occur in clusters, ${ }^{19}$ which suggests an infective agent. Further clinical and epidemiological studies are needed to determine the role of this ubiquitous viral infection in homosexual men.

We thank E Belsey for statistical analysis and J D Erdman for help with collection of the specimens.

\section{References}

1. Krech U. Complement fixing antibodies against cytomegalovirus in different parts of the world. Bull WHO 1973;49: 103.

2. Stern $H$, Elek SD. The evidence of infection with cytomegalovirus in a normal population. A serological study in Greater London. Journal of London 1965;65:79-87.

3. Meyer JD, Spencer HC, Watts JC, et al. Cytomegalovirus pneumonia after human marrow transplantations. Ann Intern Med 1975;82: 181 .

4. Weller TH. Cytomegaloviruses: the difficult years. J Infect Dis $1970 ; 122: 532$.

5. Jordan CM, Rousseau WE, Noble GR, Stewart JA, Chin TDY. Association of cervical cytomegaloviruses with venereal disease. N Engl J Med 1973;288:932-4.

6. Chretein JH, McGinnis CG, Muller A. Venereal causes of cytomegalovirus mononucleosis. JAMA 1977; 238: 1644-5.

7. Drew WL, Mintz L, Miner RC, Sands M, Ketterer B. Prevalence of cytomegalovirus infection in homosexual men. $J$ Infect Dis 1981; 143: 188-92.

8. Goldmeier D, Linch D, Mellars BJ. Immunocompromise syndrome in homosexual men. Prevalence of possible risk factors and screening for the prodrome using an accurate white cell count. Br J Vener Dis 1983;59:127-30.

9. Anonymous. Immunocompromised homosexuals. Lancet 1981;ii:1325-6.

10. Gottlieb MS, Schorff R, Schanker HM, et al. Penumocystis carinii pneumonia and mucosal candidiasis in previously healthy homosexual men: evidence of a new acquired cellular immunodeficiency. N Engl J Med 1981;305: 1425-31.

11. Bradstreet CMP, Taylor CED. Technique of complement fixation test applicable to the diagnosis of viral diseases. Monthly Bulletin of the Ministry of Health 1962;21:96-104.

12. Wentworth BB, Alexander ER. Seroepidemiology of infections due to members of the herpesvirus group. Am J Epidemiol 1971;94:496-507.

13. Griffiths PD, Campbell-Benzie A, Heath RB. A prospective study of primary cytomegalovirus infection in pregnant women. Br J Obstet Gynaecol 1980;87:308-14

14. Stagno S, Dwvorsky ME, Torres J, Mesa $T$, Hirsh $T$. Prevalence and importance of congenital cytomegalovirus in three different populations. J Pediatr 1982; 101:897-900.

15. Anonymous. Pneumocystis pneumonia-Los Angeles. MMWR 1981; 30:250-2.

16. Kornfield $\mathrm{H}$, Vande Stouwe RA, Lange M, Reddy MM, Grieco MH. T lymphocyte subpopulations in homosexual men. $N$ Engl J Med 1982; 307:729-31.

17. Giraldo G, Beth E, Kourilsky FM, et al. Antibody patterns to herpesviruses in Kaposi's sarcoma: serological association of European Kaposi's sarcoma with cytomegalovirus. Int $J$ Cancer 1975; 15: 839-48.

18. Giraldo $G$, Beth E, Henle W, et al. Antibody patterns to herpesviruses in Kaposi's sarcoma: II serological association of American Kaposi's sarcoma with cytomegalovirus. Int $J$ Cancer 1978;22: 126-31.

19. Giraldo G, Beth E, Kyalwazi SK. Etiological implications on Kaposi's sarcoma. Antibiot Chemother 1981;29:12-29.

20. Giraldo G, Beth E, Huang ES. Kaposi's sarcoma and its relationship to cytomegalovirus (CMV) III CMV, DNA and CMV early antigen in Kaposi's sarcoma. Int $J$ Cancer 1980;26:23-9. 